\begin{tabular}{ll|l} 
Volume & $: 6$ & E-ISSH: 2656-940K \\
Nomor & $: 1$ & P-ISSH: 2442-367K \\
Bulan & $:$ Februari & \\
Tahun & $: 2020$ & URL:jurnal.ideaspublishing.co.id
\end{tabular}

\title{
Efektivitas Kepemimpinan Kepala Sekolah Dasar di Kota Gorontalo
}

\author{
Novianty Djafri \\ Universitas Negeri Gorontalo \\ Surel: noviantydjafri@ung.ac.id \\ DOI: 10.32884/ideas.v6i1.263
}

\begin{abstract}
Abstrak
Tujuan penelitian ini adalah untuk mengetahui gambaran efektivitas kepemimpinan kepala sekolah dasar di Kota Gorontalo. Metode yang digunakan pada penelitian yaitu survei dengan jenis penelitian kualitatif dan pendekatan deskriptif. Populasi penelitian berjumlah 156 kepala sekolah dengan sampel 66 Kepala Sekolah Dasar di Kota Gorontalo, yang dianalisis melalui angket, sedangkan untuk menemukan data profil sekolah dilakukan melalui data observasi dan wawancara dengan menyajikan sumber data primer dan sekunder. Hasil temuan dalam penelitian yaitu hasil analisis efektivitas Kepemimpinan kepala sekolah berada pada kategori baik, dengan hasil 82,21\%, dengan indikator; a) kepala sekolah sebagai edukator;b) kepala sekolah sebagai manajer; c) kepala sekolah sebagai administrator;d) kepala sekolah sebagai supervisor;e) kepala sekolah sebagai leader, danf) kepala sekolah sebagai inovator.
\end{abstract}

Kata kunci:efektivitas, kepemimpinan, kepala sekolah dasar

\section{Pendahuluan}

Sebagaimana disadari bahwa sekolah adalah salah satu jenis organisasi yang sering disebut organisasi pendidikan formal. Salah satu unsur organisasinya yang paling penting adalah manusia di dalamnya. Personel interen organisasi sekolah terdiri dari kepala sekolah, guru-guru, siswa/siswi, dan pegawai tata usaha sekolah.Kegiatan pokok yang mereka kerjakan adalah kegiatan belajar mengajar.

Sekolah sebagai lembaga formal pendidikan memegang peranan penting dalam meningkatkan kualitas pendidikan melalui pembelajaran untuk menunjang kelancaran jalannya pembangunan di Indonesia secara keseluruhan. Sumber daya manusia unggul merupakan persyaratan utama bagi terwujudnya bangsa dan negara yang maju. Berapapun besar sumber daya alam (SDA) dan modal sarana prasarana yang tersedia, pada akhirnya target pembangunan bangsa dan negara dapat dicapai dengantangan SDM yang handal. Perspektif berpikir seperti ini menunjukkan bahwa suatu bangsa tidak dapat mencapai kemajuan tanpa adanya suatu sistem pendidikan yang baik. Pendidikan adalah modal dasar untuk menciptakan SDM yang unggul.

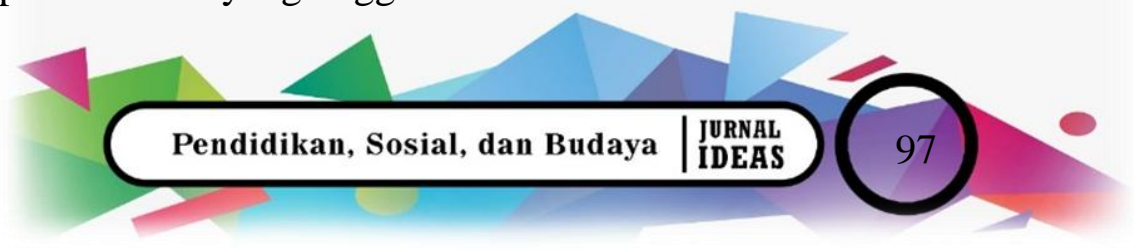




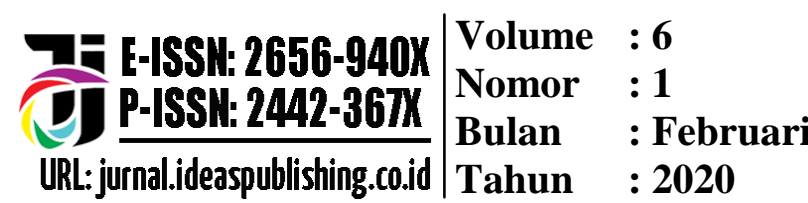

Diantara pemimpin-pemimpin pendidikan yang bermacam-macam jenis dan tingkatannya, kepala sekolah merupakan pemimpin pendidikan yang sangat penting. Dapat terlaksana atau tidaknya tujuan pendidikan, sangat tergantung pada kecakapan dan kebijakan kepala sekolah dalam memimpin suatu sekolah atau lembaga yang dinaunginya. Keberhasilanpendidikan di sekolah sangat ditentukan oleh keberhasilan kepala sekolah dalam mengelola tenaga kependidikan yang tersedia di dalamnya(Karwati dan Priansa, 2013, hlm. 2).Kepala sekolah dengan tugas dan fungsinya melaksanakan fungsi-fungsi manajemen, melalui: POAC (Planning, Organizing, Actuiting dan Controlling).

Pada observasi awal di sekolah dasar Kota Gorontalo, ditinjau dari kegiatan setiap hari kerja masih ditemukan ada sebagian guru dan pegawai yang belum dapat menyiapkan pembelajaran secara tertib dan datang tepat waktu di sekolah. Oleh karena itu, peneliti merasa perlu untuk melakukan studi lanjut untuk mengobservasi lebih jauh melalui penelitian "Efektivitas Kepemimpinan Kepala Sekolah Dasar di Kota Gorontalo". Tujuan penelitian iniadalah untuk mengetahui efektivitas kepemimpinan sekolah dasar di kota Gorontalo.

Sekolah merupakan salah satu bentuk organisasi pendidikan. Kepala Sekolah merupakan pemimpin pendidikkan di sekolah. Sebagai pemimpin pendidikan, kepala sekolah memilikisejumlah tugas dan tanggung jawab yang cukup berat. Menjalani fungsinya secara optimal, maka kepala sekolah perlu menerapkan gaya kepimimpinan yang tepat. Wahjosumidjo (2013, hlm. 3) mengartikan bahwa kepala sekolah adalah seorang tenaga fungsional guru yang diberi tugas untuk memimpin suatu sekolah dimana diselenggarakan proses belajar mengajar atau tempat dimana terjadi interaksi antara guru yang memberi pelajaran dan murid yang menerima pelajaran. Berkaitan dengan kepemimpinan kepala sekolah dalam Rusmawati (2013, hlm. 3) kepemimpinan kepala sekolah memberikan motivasi kerja bagi peningkatan produktivitas kerja guru dan hasil belajar siswa.

Kepemimpinan kepala sekolah harus benar-benar dapat dipertanggungjawabkan, karena tanggung jawab kepala sekolah sangat penting dan menentukan tinggi rendahnya hasil belajar para siswa. Selain itu, produktivitas dan semangat kerja guru tergantung kepala sekolah, dalam arti sampai sejauh mana kepala sekolah mampu menciptakan 


\begin{tabular}{ll|l} 
Volume & $: 6$ & E-ISSH: 2656-940X \\
Nomor & $: 1$ & P-ISSH: 2442-36TK \\
Bulan & $:$ Februari & PR: jurnal.ideaspublishing.co.id \\
Tahun & $: 2020$ & URL
\end{tabular}

kegairahan kerja dan sejauh mana kepala sekolah mampu mendorong bawahannya untuk bekerja sesuai dengan kebijaksanaan dan program yang telah digariskan sehingga disiplin, produktivitas kerja, dan kinerja guru menjadi tinggi dan hasil belajar siswa dapat meningkat.

Ada banyak teori gaya kepemimpinan yang biasa diterapkan kepala sekolah. Bila ditelaah dari perkembangan teori, ada banyak teori kepemimpinan yang bisa ditelaah untuk mengkaji masalah kepemimpinan. Teori kepemimpinan yang pertama-tama dikembangkan adalah teori sifat atau trait theory.

Teori sifat memandang bahwa keefektifan kepemipinan tersebut bertolak dari sifat atau karakter yang dimiliki seseorang. Keberhasilan kepemimpinan itu sebagian besar ditentukan oleh sifat-sifat kepribadian tertentu, misalnya harga diri, prakarsa, kecerdasan, kelancaran berbahasa, kreativitas. Semua hal tersebut, termasuk pula ciriciri fisik yang dimiliki seorang pemimpin yang dikatakan efektif bila memiliki sifatsifat kepribadian yang baik.

Menurut Rivai (2009, hlm.148), peran dapat diartikan sebagai perilaku yang diatur dan diharapkan dari seseorang dalam posisi tertentu. Pemimpin di dalam organisasi mempunyaiperanan. Setiap pekerjaan membawa serta harapan bagaimana penanggung peran berperilaku. Peran kepemimpinan dalam tim menurut kepemimpinan yang berorientasi pada memelihara kelompok yaitu: a) penjagaan gawang (gatekeeping);b) mengharmoniskan (harmonizing); c) mendukung (supporting); d) menerangkan standar (standard setting); dan e)menganalisis proses (analyzing process).

Kepemimpinan khususnya di lembaga pendidikan memiliki ukuran atau standar pekerjaan yang harus dilakukan oleh kepala sekolah selaku pimpinan tertinggi. Menurut Mulyasa (2009, hlm. 90) bahwa seorang kepala sekolah harus melakukan perannya sebagai pimpinan dengan menjalankan fungsi sebagai berikut. Berikut penjabarannya.

1. Kepala Sekolah sebagai Edukator

Menurut Mulyasa (2009, hlm. 98), kepala sekolah sebagai edukator harus senantiasa berupaya meningkatkan kualitas pembelajaran yang dilakukan oleh para guru. Faktor pengalaman dalam hal ini akan sangat memengaruhi profesionalisme kepala sekolah, terutama dalam terbentuknya pemahaman tenaga kependidikan terhadap pelaksanakan tugasnya. Pengalaman semasa menjadi guru, menjadi wakil kepala 


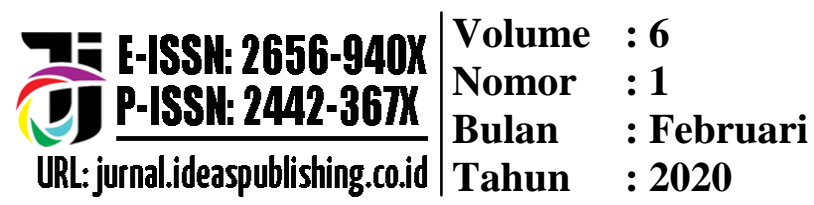

sekolah, atau menjadi anggota organisasi kemasyarakatan sangat memengaruhi kemampuan kepala sekolah dalam melaksanakan pekerjannya.Demikian halnya pelatihan dan penataran yang pernah diikutinya.

2. Kepala Sekolah sebagai Manajer

Kepala sekolah harus memiliki strategi yang tepat untuk memberdayakan tenaga kependidikan melalui kerja sama atau kooperatif, memberi kesempatan kepada tenaga kependidikan untuk meningkatkan profesinya, dan mendorong keterlibatan seluruh tenaga kependidikan dalam berbagai kegiatan yang menunjang program sekolah(Mulyasa, 2009, hlm. 101).

3. Kepala Sekolah sebagai Admnistrator

Kepala sekolah sebagai administrator, khususnya dalam meningkatkan disiplin kerja dan produktivitas sekolah, dapat dianalisis berdasarkan beberapa pendekatan, baik pendekatan sifat, pendekatan perilaku,maupun pendekatan situasional(Mulyasa, 2009, hlm. 105).

4. Kepala Sekolah sebagai Supervisor

Supervisi merupakan suatu proses yang dirancang secara khusus untuk membantu para guru dan supervisor dalam mempelajari tugas sehari-hari di sekolah agar dapat menggunakan pengetahuan dan kemampuannya untuk memberikan layanan yang lebih baik pada orang tua peserta didik dan sekolah, serta berupaya menjadikan sekolah sebagai masyarakat belajar yang lebih efektif(Mulyasa, 2009, hlm.107).

5. Kepala Sekolah sebagai Leader

Mulyasa (2009, hlm.200) mengemukakan bahwa kepala sekolah sebagai leader harus memiliki karakter khusus yang mencakup kepribadian, keahlian dasar, pengalaman dan pengetahuan professional, serta pengetahuan administrasi dan pengawasan.

6. Kepala Sekolah sebagai Inovator

Menurut Mulyasa (2009, hlm. 201) kepala sekolah harus memiliki strategi yang tepat untuk menjalin hubungan yang harmonis dengan lingkungan, mencari gagasan yang baru, mengintegrasikan setiap kegiatan, dan memberikan teladan.

Peran pemimpin menjadi mudah untuk dilakukan, mengingat keberhasilannya bukan hanya karena kualitas pribadi melainkan bagaimana pemimpin tersebut memiliki 


\section{Volume : 6 \\ Nomor : 1 \\ Bulan : Februari \\ Tahun : 2020 E-ISSH: 2656-940X 군 P-1SSH: 2442-367X प्रे URL: jurnal.ideaspublishing.co.id}

karakter dan kompetensi dalam mengarahkan organisasi menuju visi dan misi yang telah ditetapkan didalamnya terdapat pengambilan keputusan, pengendalian konflik, dan membangun tim.

Berdasarkan uraian diatas maka, kepemimpinan kepala sekolah disintesiskan pada indicator: a) kepala sekolah sebagai educator; b) kepala sekolah sebagai manajer; c) kepala sekolah sebagai administrator; d) kepala sekolah sebagai supervisor; e) kepala sekolah sebagai leader; dan f) kepala sekolah sebagai inovator.

\section{Metode}

Metode yang digunakan adalah metode survei dengan jenis penelitian kualitatif dan pendekatan deskriptif. Populasi adalah 156 dengan sampel penelitian adalah 66 orang Kepala Sekolah Dasar di kota Gorontalo yang dianalisis melalui angket.Sedangkan untuk menemukan data profil sekolah, melalui data observasi dan wawancara, dengan menyajikan sumber data primer dan sekunder (Mulyasa, 2009:24).

\section{Hasil dan Pembahasan}

Berdasarkan hasil observasi ataupun tinjauan langsung dilapangan, peneliti menemukan kondisi sekolah melalui perwakilan data profil sekolah SDN No. 68 dan MIM, juga melalui observasi pengamatan dan wawancara dengan kepala sekolah dan guru, bahwa kondisi beberapa sekolah negeri memiliki gedung sekolah, dengan sejumlah guru PNS, namun belum memiliki sarana dan prasaran yang lengkap. Hal ini menunjukkan kurangnya kepala sekolah sebagai manajer.

Adapun hasil wawancara dengan kepala sekolah SDN No. 68, sekolahnya memiliki gedung, ruang kelas dari 1-6, ruang kepala sekolah dan staf dewan guru kelas, UKS dan perpustakaan, serta rumah guru, kantin (yeni/w/2 Oktober 2018). Namun untuk sekolah MIM, dari hasil observasi hanya memiliki 1 gedung yaitu untuk siswa kelas 5-6, ruang kepala sekolah dan staf dewan guru kelas 5-6, UKS, dan koperasi. Gedung ke-2 untuk ruang kelas 1-4, perpustakaan,UKS aula, lab computer, dan kantin. Gedung yang terbagi dua ini membuat sebagian guru dan pegawai sedikit berpikir bahwa sekolah ini memiliki dua kepala sekolah. Dasar pemikiran tersebut karena: 1) terkadang ditemukan informasi antara gedung 1 dan gedung 2 berbeda, dengan perintah 


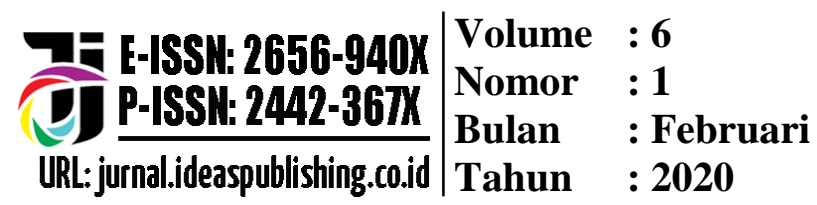

dari 2 orang yang berbeda di gedung 1 Kepala Sekolah Madrasah dan di gedung 2 ada wakil kepala sekolah; 2) terkadang aturan-aturan yang dikeluarkan berbeda di antara 2 pengambil keputusan tersebut; 3) staf guru dan pegawai tidak terpantau dengan baik terkait hal-hal yang lakukan di setiap hari. Hal ini menunjukkan kurangnya kepala sekolah sebagai administrator.

\section{Efektivitas Kepemimpinan Kepala Sekolah Dasar}

Tabel 1

Efektivitas Kepemimpinan Kepala Sekolah Dasar Kota Gorontalo

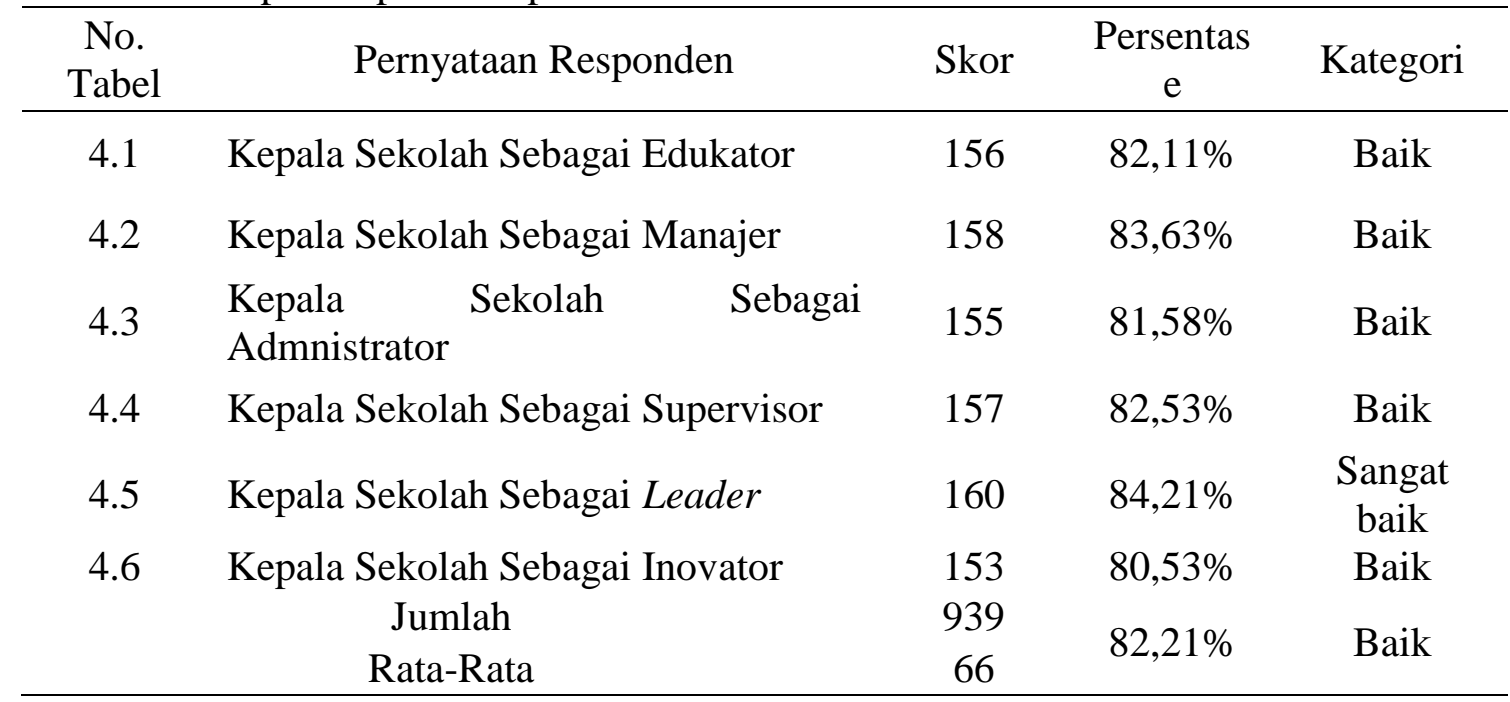

Sumber: Data diolah, 2015

Efektivitas kepemimpinan kepala sekolah sebagai leader memiliki nilai tertinggi karena: 1) kepala sekolah belum benar-benar memantau anak buahnya atau anggotanya. Contohnya, masih ada guru dan pegawai yang datang tidak tepat waktu, kelalaian petugas keamanan (satpam) yang sering meninggalkan pintu jaga, menghilang saat dibutuhkan dalam hal pengamanan; 2) sampai dengan sekarang belum ada tindak lanjut ataupun ketegasan aturan atas siswa-siswa yang sering terlambat;3) kepala sekolah belum benar-benar memperhatikan dan belum begitu tegas dalam pemberian penghargaan serta hukuman pada guru atau pegawai.

Kepemimpinan kepala sekolah sebagai inovator, memiliki nilai terendah.Hal ini diakibatkan oleh rendahnya output bawahan dalam merespon kreativitas pimpinan. Dengan demikian, kepala sekolah dasar sebagai inovator harus lebih meningkatkan kepemimpinan yang motivator, diantaranya: 1) kepala sekolah sebagai inspiratif yang ramah tidak pernah memandang status dan memperlakukan sama sehingga guru dan staf 


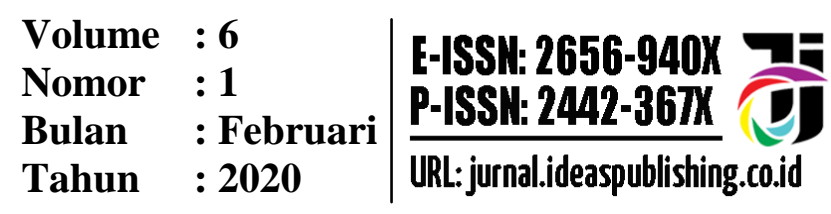

tidak merasa tertekan dalam melakukan tugasnya dan mengembangkan kreativitasnya; 2) kepala sekolah selalu berusaha melibatkan seluruh guru dan staf tata usaha dalam mengambil keputusan serta menerima saran ataupun tanggapan dari guru-guru agar mereka lebih berinovasi; 3) kepala sekolah selalu cepat dalam menyelesaikan konflik, baik antara guru, orang tua siswa dan guru, maupun antarsiswa. Kepala sekolah selalu berusaha menjadi penengah antar kedua pihak tanpa memihak satu di antara yang lain. Terkadang konflik ada karena kurangnya pemahaman untuk yang mengeluarkan pendapat dan berekspresi, sehingga salah pemahaman antar pihak sekolah.

Efektivitas kepemimpinan merupakan proses yang memengaruhi orang lain untuk mengambil langkah-langkah atau tindakan menuju suatu sasaran bersama. Oleh karena itu, kepemimpinan adalah kegiatan memengaruhi orang lain agar mau bekerja untuk mencapai tujuan yang telah ditentukan. Hal tersebut sesuai dengan yang dijelaskan oleh hal tersebut sesuai dengan pendapat Rohmat (2012, hlm. 3) bahwa kepemimpinan pendidikan memerlukan perhatian yang utama, karena melalui efektivitas kepemimpinan yang baik diharapkan akan lahir tenaga-tenaga pendidik yang berkualitas dalam berbagai bidang sebagai pemikir maupun pekerja yang pada akhirnya dapat meningkatkan sumberdaya manusia yang berkualitas.

\section{Simpulan}

Kepemimpinan kepala yang efektif dapat diperoleh melalui data profil sekolah, namun untuk mendapatkan hasil efektivitas kepemimpinan kepala sekolah dalam mengelola suatu organisasi pendidikan/sekolah dasar, dapat dilakukan melalui kepemimpinan yang berkualitas, sebaik apapun kepemimpinan kepala sekolah tetap akan ada kekurangan (negatifnya) dan juga kelebihannya (positifnya). Sekolah yang maju sekalipun pasti ada kekurangannya, bagi yang melihat sekedarnya saja pasti akan beranggapan sebagaimana yang dilihatnya. Namun untuk sekolah yang memiliki kepala sekolah yang efektif mengelola pendidikan dengan baik, pasti mendapatkan penilaian dan respon terbaik dari masyarakat.Oleh karena itu, kepemimpinan kepala sekolah dasar harus terus efektif untuk meningkatkan indikator: a) kepala sekolah sebagai edukator; b) kepala sekolah sebagai manajer; c) kepala sekolah sebagai administrator; d) kepala

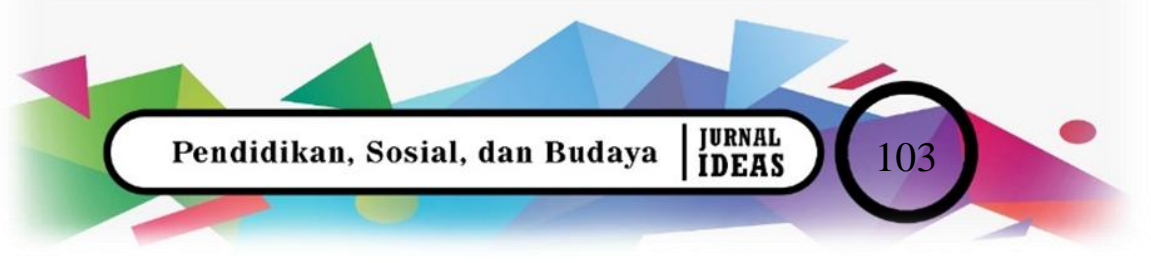




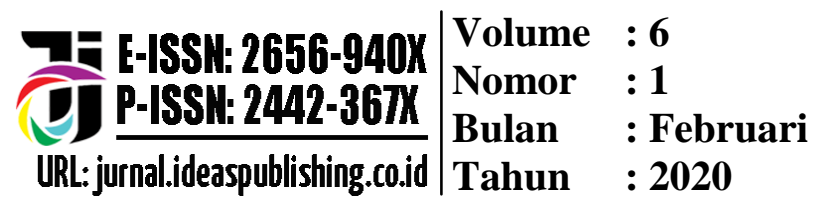

sekolah sebagai supervisor; e) kepala sekolah sebagai leader; dan f) kepala sekolah sebagai inovator.

\section{Daftar Pustaka}

Karwati, E. dan Priansa, D. J.(2013). Kinerja dan Profesionalisme KepalaSekolah: Membangun Sekolah yang Bermutu. Bandung: Alfabeta.

Mulyasa. (2009). Menjadi kepala Sekolah Profesional. Bandung: Rosda karya.

Mulyasa. (2009). Praktik Penelitian Tindakan Kelas. Bandung: Rosda Karya.

Rivai (2009).Manajemen Sumber Daya Manusia. Jakarta:Cetakan kesembilan.

Rohmat. (2010). Kepemimpinan Pendidikan Konsep dan Aplikasi. Purwokerto:STAIN Press.

Rusmawati, Vivi. (2013), Peran Kepemimpinan Kepala Sekolah Dalam Upaya Meningkatkan Disiplin Kerja Guru Pada SDN 018 Balikpapan.Ejournal Administrasi Negra, 1 (2): 395-409. Universitas Mulawarman.

Wahjosumidjo. (2013). Kepemimpinan Kepala Sekolah: Tinjauan Teoritik danPermasalahannya, Jakarta: Raja Grafindo Persada. 